Article

\title{
Consumer Empowerment in the Digital Economy: Availing Sustainable Purchasing Decisions
}

\author{
Patrizia Gazzola ${ }^{1}{ }^{*}$, Gianluca Colombo ${ }^{2}$, Roberta Pezzetti ${ }^{1}$ and Luminița Nicolescu ${ }^{3}$ \\ 1 Department of Economics, University of Insubria, 21100 Varese, Italy; robertarita.pezzetti@uninsubria.it \\ 2 Department of Management, Università della Svizzera Italiana, USI, 6900 Lugano, Switzerland; \\ gianluca.colombo@usi.ch \\ 3 Department of International Business and Economics, Bucharest University of Economic Studies, \\ 010374 Bucharest, Romania; luminita.nicolescu@rei.ase.ro \\ * Correspondence: patrizia.gazzola@uninsubria.it; Tel.: +39-0332-395529
}

Academic Editor: Giuseppe T. Cirella

Received: 19 March 2017; Accepted: 21 April 2017; Published: 27 April 2017

\begin{abstract}
The advent of the digital economy and, implicitly, of competition in the online marketplace has triggered new challenges in terms of consumer protection approaches. Online, consumer skills are expected to be improved and the level of consumer awareness and engagement increased. These are the baseline prerequisites of the sustainable purchasing decision and, thus, should be considered as pillars of responsible online consumption. Consistent with the novel consumption challenges, the current paper is intended to advance and test a research model integrating five main constructs, namely, competition in the online marketplace, online consumer skills, online consumer awareness, online consumer engagement and sustainable purchasing decision. A total of 318 college students-a representative population of the new Millennials generation-accepted the invitation to participate in a questionnaire-based survey. In order to pertinently analyze the collected data, a structural equation modeling technique based on partial least squares was employed for the assessment of the measurement and the structural model. The findings indicated that the model explained 24.4 percent of the variance of sustainable purchasing decisions, while the highest influence was exerted by the improvement of online consumer skills. This implies that online providers should revisit their products sustainability standards on purpose to preserve a competitive advantage.
\end{abstract}

Keywords: competition; online consumer skills; consumer awareness; consumer engagement; sustainable purchasing decision

\section{Introduction}

Over the past several years, the digital economy has set itself up as a complex structure comprising a fast-growing number of nodes and links, assets and services which are connected via complex networks made of intertwined value chains [1-3]. Based on technologies involving a strong connection to the Internet [1] (p. 15), the digital economy poses new challenges in terms of the extension of products and customer service markets with an unprecedentedly rapid rhythm, as different facts and figures report [4] (p. 12). For example, the gross revenues generated by only one sector in the digital economy, namely the collaborative economy, doubled in the European Union (EU) in 2015 when compared to 2014, and reached an estimated $€ 28$ billion [5] (p. 1). Moreover, at the moment, nearly $40 \%$ of the world's population has access to the digital economy (or the Internet economy) [6] (p. 5), and while the Internet- the means of access to this system—"remains unavailable, inaccessible, and unaffordable to a majority of the world's population", mostly living in India, China, and the countries outside of the top 20, the situation is rapidly changing [6] (p. 8), [7]. 
As the digital economy welcomes constant innovation and competition in the business sector, it also triggers consumer welfare [8]. By making available to consumers services and products that they were not previously able to access, the increasing incorporation of digital technologies in both the business and public sectors stimulate trade operations [6] (p. 12), reframe marketing practices [9] and generate a substantive shift in people's behavior [10-14].

The expected positive results of the digital revolution, steadily taking over the world economies, are accompanied by a series of concerns regarding the capacity to control the ongoing transformative processes. New business models challenge the existing policy framework at various levels: competition policy, consumer protection, privacy, taxation, and intellectual property rights [1] (p. 9), [15]. Without complementary developments, such as regulation and the improved skills and institutions to help implement these regulations, the accelerated growth opportunities that the digital technology may offer could be replaced by unexpected risks [6] (p. 5). For example, the automation of Internet-based services leads to low marginal costs that are related to large economies of scale and favor natural monopolies that could be detrimental to consumers in the absence of regulation to protect their interests [6] (p. 13). As the existing regulatory and standards frameworks tend to evolve slower than the digital revolution blooms, various concerns regarding the fact that "consumer protection mechanisms are being outmoded and outpaced by the speed of change in the digital economy" have already been voiced [16] (p. 1).

Much of the existing research related to connections between the digital technology and the economic sector focuses on the need to create new legislation and to enforce it. While regulatory frameworks differ in the EU, North America and other parts of the globe, both consumer protection and competition policies are topics of interest [1,16-22]. Consumer protection would be effectively increased only by additional or revised legislation, and by the political and/or regulatory intervention along with direct consumer demand [23]. These factors have been noted as key drivers of the inherent advances between 2012 and 2015 [16] (p. 3), [4] (p. 12).

The power that consumers have over companies in the new economic model, where formal regulations sometimes lack or they are difficult to apply, has been briefly addressed in recent years [18]. At the EU level, a Consumer Empowerment Index (integrating consumer skills, awareness of legislation on consumer rights and consumer engagement) was calculated, although it does not entirely apply to the particularities of the digital economy [24]. Still, it is a relevant starting point for interpreting the influence of competition — as availed by the digital economy—on consumers' actions and reactions in the online marketplace.

Empowered consumers are liable to drive innovation, productivity and competition [25] by means of education, access to relevant information and capacity to assess information correctly, in order to make optimal decisions as buyers [26] (pp. 12-16). They leverage the possibility to exchange opinions and views to the extent that a new type of consumer emerges: "the prosumer" [27], a rational consumer who gathers knowledge about products and services, participates actively in the market by sharing her/his knowledge on purpose to reduce uncertainty [28-31]. They have capitalized the opportunity to make purchasing decisions and, now, the well-informed, educated and active consumers play the role of the driver of competition in the marketplace [18] (p. 27).

Building on this logic and on the seminal literature linking competition, consumer empowerment and sustainable purchasing decisions, the current paper is intended to address the relationships among these main constructs. As previously mentioned, consumer empowerment is operationalized by means of three pillars (i.e., consumer skills, awareness of legislation on consumer rights, and consumer engagement), according to Nardo et al.'s [24] taxonomy. The approach is in line with the European Commission's position acknowledging that "consumer empowerment is both a function of the skills, knowledge and assertiveness of consumers themselves, and the protection, rules and institutions designed to support them as they play their part" [32] (p. 8). Thus, it depends simultaneously on good cognitive skills, knowledge of consumer rights and specific authorities, and accessible means of redress.

The emphasis of this research is laid on the young generation, the so-called Millennials, thus giving credit to the Organisation for Economic Co-operation and Development (OECD)'s findings [33] 
regarding the differences by age group in terms of consumption patterns and interest in sustainable consumption. The OECD's study gathered data from seven European countries, including Italy, and posited that Millennials "tend to be very conscious of the need to reduce environmental pollution, improve human health and increase respect for human rights on a global scale. They believe their generation is consuming too much and want more information on how to reduce the negative ecological and social impacts of their consumption" [33] (p. 47).

Taking into consideration the aforementioned arguments, the article is structured as follows: the second section depicts the theoretical background and the development of hypotheses; the third section describes the materials and methods, namely the data collection and sample, measures and measurement and structural model assessment; the fourth and fifth sections are focused on the results and discussion of findings in terms of research contribution and originality, theoretical and practical implications and limitations, and future research directions.

\section{Theoretical Background and Hypotheses Development}

The first correlation approached within the conceptual model refers to the relationship between competition and consumer empowerment. Hereby, competition is defined in line with the classical definition of Clark cited in Delp and Mayo [34], which integrates three pivotal components, that is, the existence of rivalry among product or service providers, the free choice of consumers to purchase from different sellers and the providers' endeavors to leverage the attractiveness of their offers. This perspective lays the foundation of competition in the digital economy, of e-commerce in particular, as contended by Delp and Mayo in 2016 [34] (p. 17)_-"(1) Firms exhibit overt rivalry in their quest for consumer patronage; (2) Consumers have choices among vendors, readily demonstrate their ability to change vendors, and vendors ( ... ) have the ability and propensity to expand output to satisfy consumer demands; (3) Rivalry among vendors manifests itself in desirable economic performance metrics, including price, output, quality, investment, and innovation".

Within this framework and pursuant to the European Commission's [32] (p. 11) vision, consumer empowerment sets itself up as "a multifaceted compound measure", operationalized through the data on consumer skills, knowledge of consumer rights and consumer engagement. In the light of an increasingly dynamic competition and digital information overload, consumer empowerment derives as a key factor in making optimal choices in liberalized markets. In order to become empowered, consumers are determined to: (1) thoroughly understand the choices available to them in terms of providers' offerings, thus improving their online skills (i.e., compare offers and check where to buy the cheapest desired product, check online sales or promotions, talk to the customer service assistant about additional product details, resort to customers' online reviews regarding their experience in buying from a certain website before acting, perform cost-benefit analyses before buying products online); (2) be aware of and know their rights and recognize detriment, thus improving their online awareness (i.e., be aware of my consumers' rights when buying on sales online, of the agencies (government and voluntary) offering consumers guidance, of the legal action of governmental and non-governmental institutions on protecting consumers, of consumers' distance-purchasing rights, of different sources of information about consumer affairs, of consumer online communities debating on consumers policies) and (3) engage themselves in specific redress actions whenever their rights are breached (i.e., give a poor quality product back to the online seller and demand money refund, demand replacement of a poor quality product bought online for a good one, give a poor quality product back to the manufacturer for repair (production plant/factory) on the basis of the warranty card) [32] (p. 24). In the context of the present research, the sub-pillar of consumer engagement, namely detriment and redress, was primarily considered, as the most prominent facet of consumer behavior, hence, going beyond attitude towards action.

Given the operationalization of the two constructs-competition and consumer empowermentand of the latter's components (consumer skills, awareness and engagement), the relationship between the variables identified has been widely acknowledged by the extant literature. According to Fatas 
and Lyons [35] (p. 29), competition objectivized through "firms fight for customers by offering them a better deal in terms of price, quality, range, reliability or associated services" triggers the imperative that consumers acquire information on these alternative offers and act rationally based on this information. Likewise, Laitenberger [36] (pp. 6-8) and Bauer and Erixon [37] (pp. 4-8) clearly state that information technology and, implicitly, competitive digital businesses possess a substantive potential to integrate markets and empower consumers "so that markets work better and consumer welfare is enhanced" [36] (p. 8).

The same line of thought is revealed by the OECD [38] (p. 7) which contends that "digital technologies are rapidly reshaping existing markets" in terms of competition dynamics, providing novel ways to connect customers with suppliers and to empower consumers to adjust their behavior in response to the information acquired. Moreover, the OECD [39] (pp. 8-9) firmly recognizes the dynamic and competitive nature of the e-commerce arena, "which enables consumers to gather, compare, review and share information about goods and services, and fosters the development of new business models, some of which facilitate consumer-to-consumer transactions ( . . ) dispute resolution and redress". Beranek and Kamerschen [40] put it simply, by pointing to one of the major foundations of competition which resides in "the existence of alternatives to the product the consumer wants. (... ) They must be discovered, their costs identified, and their usefulness evaluated". All these endeavors engender shopping skills which involve the knowledge to collect an information base regarding the offerings envisioned by consumers. In this vein, the authors underscore that "in sum, competition can bring a whole constellation of net consumer improvements ( ... ). Potential immediate benefits from enhanced individual skills are only beginning to be recognized; but society has yet to realize the immense secondary benefits from added competition".

In the overall framework of competition and consumer empowerment, the relationship between competition and online consumer skills has been intensively discussed in the European Union. As the OECD emphasizes: "growth in the use of online technologies for work, leisure, electronic commerce and other activities has greatly increased the need for consumers to develop digital competence" [38] (p. 12). The imperative is that consumers enhance their knowledge of technology, to properly disentangle a wide spectrum of online offers to their best interests. The fierce competition in the digital marketplace forces consumers to improve their level of understanding and instrumental competence to manage online purchases.

Drawing upon online consumer skills, the OECD [38] affirms that empowered consumers are able to better explore and identify optimal prices (sales, promotions), the highest quality (by asking the customer service assistant about additional product details, by read other customers' online reviews regarding their experience in buying) and perform responsible choices in terms of cost-benefit analyses. Browsing for the best alternatives to the products of interest is, thus, a prominent derivative of effective competition. Offerings are not available per se, they are supposed to be discovered, the prices analyzed, and the deliverables carefully assessed. In this respect, all the activities performed require improved online consumer skills $[32,38]$. This is why the digital economy and e-commerce, in particular, create major prerequisites for consumer control over decision-making, especially when the choice is wider [40,41]. That being the case, we infer that:

Hypothesis 1. Competition in the online marketplace has a positive influence on online consumer skills.

Given the fast-growing competition in the digital marketplace, consumers are also directed towards the importance of knowing their rights and responsibilities when performing online purchases [38] (p. 13). It is not enough to only have knowledge of technology and media, it is necessary to gain awareness of consumer rights and legal protection tools when conducting online transactions. As the OECD [39] (p. 18) advances, "awareness programmes aimed at providing them with relevant knowledge and skills to access and use digital technology to participate in e-commerce" are of the essence. Similarly, Mwakatumbula et al. [41] (pp. 9-10) urge that consumers should possess 
a reasonable knowledge of their rights and obligations and become aware of complaint procedures and tools. Starting from this premise, we presume that:

Hypothesis 2. Competition in the online marketplace has a positive influence on online consumer awareness of the legislation on consumer rights.

With a view to ensure consumers efficiently engage in the online marketplace, consumer empowerment in terms of the establishment and exercise of consumer protection laws and regulations is paramount [41] (p. 9). Pursuant to Mwakatumbula et al. [41] (pp. 9-10), "for consumers to fully exploit the intended benefits extended by these competitive markets, they should actively engage in the market". One of the most obvious forms of consumer engagement, from a behavioral perspective, is manifested whenever consumers' rights are breached and they actually act to get redress. By playing their role in an efficient manner, consumers are liable to potentiate their welfare and drive competition for the growth of the entire industry. This approach is also indicative of the European Commission's vision in that "empowered consumers who complain and assert their rights are the most effective consultants in helping businesses to innovate and improve" [32] (p. 24). In this light, online customers militate for empowerment, not control and "this evolution from control to empowerment means a change in the basic building blocks of customer engagement" [42]. Focusing on this perspective, we infer that:

Hypothesis 3. Competition in the online marketplace has a positive influence on online consumer engagement.

Linking consumer empowerment to sustainable purchasing decisions, Case [43] defines the latter as the process of buying products with improved sustainability footprints, thus, conforming to price, performance and quality requirements. On this front, consumers dispose of a variety of tools to set the parameters for sustainable purchasing, for example, buying products online (as providers are more controlled by the authorities), contrasting offers against various product specifications (products certified to environmental leadership standards), comparing products in terms of quality and sustainability (by analyzing environmental labels, identifying the greener, healthier products), and acquiring information from other customers' experiences and reviews. In other words, sustainable purchasing decisions emerge at the crossroads of online consumer skills, awareness and engagement.

According to Maher et al. [44], the choices made by consumers entail substantial social, economic and environmental implications as regarding sustainability. Over the last several years, different stakeholders paid heed to developing ways to gain consumers' support for sustainable consumption and for sustainable purchasing decisions. At this level, one of the main goals to be achieved focuses on consumer empowerment by means of "(i) increasing awareness of the importance and benefits of sustainability, both for individuals and society, (ii) developing practical knowledge of what consumers can do to support sustainable consumption, and (iii) providing necessary skills and attitudes for putting this knowledge into everyday practices" [44] (p. 9).

This is why success on achieving sustainable consumption mainly relies on the prerequisites of decision making [45], and as Wright, Newman and Dennis content, "the ultimate decisions are made by consumers through their various abilities to exercise their choices of whether to buy or not to buy. (... ) These are consumer empowerments" [46] (p. 926). Whenever online consumers exercise their skills and ability to compare the unit prices and specification of products, supported by EU law, they step towards optimal decision-making as regards sustainable purchasing [32] (p. 10). Here, it is worth mentioning that online customers may be interested in collecting data on specific environmental issues, but they also may be interested in consulting with other parties for validation, in sharing success stories and the lessons learned [47,48]. "Labelling, branding and design can aid consumers in making personal messages about the sustainability of their purchases" [33] (p. 47), but as Case [47] posits, there a lots of situations where online consumers "don't want to know that a product meets someone else's definition of green. They want to review the data and decide for themselves". Based on this logic, we presume that: 
Hypothesis 4. Online consumer skills have a positive influence on the sustainable purchasing decision.

Even though there are voices who stress the fact that consumer protection plays a leading role in building a safer world $[14,49,50]$, preventing sellers from increasing their sales by means of deceptive marketing or by engaging in unfair practices [51], Euromonitor International's report [52] argues that the real power pertains to empowered consumers. In this respect, Millennials are credited among the most empowered consumers, being described as a generation highly dependent on technology and permanently "wired" [52,53]. They consistently develop a socially responsible view on consumption and adhere to a sustainability framework in their general orientation, demanding transparency and sustainable actions from the companies they interact with [54-57]. Put in simple words, these empowered consumers vote with their wallets by paying heed to product labels and making responsible purchasing choices. Young change-makers show an increasing interest in placing authenticity and sustainability above convenience and hazard, that is, Millennials "seek products that are sustainable, ethical, artisanal, repairable and long-lasting" [52] (p. 4).

According to the European Commission's perspective [32] (p. 9), generally there is a "low level of knowledge regarding consumer rights with potentially significant implications for consumer detriment and decision-making". A better awareness of the existing rights and of their application would improve consumers' welfare and strengthen their responsible decisions in terms of sustainable purchasing. By investing in their awareness and knowledge on consumer policy, Millennials are steadily growing in their influence [58], putting pressure on businesses to be more sustainable. Companies that fail to prove their reliability in environmental and social responsibility risk estranging the Millennials group both as customers [59] and employees [60].

Young adults are also able to influence the purchasing habits of their families as sustainability is a key concern for the Millennials generation [61]. Several empirical surveys identify Millennials as the most sustainable generation to date [52,62-64]. In particular, the search for sustainable behavior is pushing Millennials to adopt new consumer habits, more in line with their values [40], which translate into their willingness to pay more for eco-friendly and ethical products and services. In line with Nielsen's Millennials Drive Sustainability Survey [62], a simple act of selecting a product or service becomes a potential statement about their identity and personal values, which are more important than personal benefits (such as cost or convenience).

In fact, half of Millennials believe that brands "say something" about "how they fit in the world as a whole, and 59\% are willing to pay more for a brand that portrays the right image" [62]. A myriad of studies indicate that sustainability awareness is driving Millennials' purchase choices and loyalty attitudes in various sectors and industries such as: the food and beverage industry, clothing, healthcare and wellness industry, household and personal care industry, the interactive technologies industry, etc. $[61,62,64-72]$. By corroborating the arguments, we infer that:

Hypothesis 5. Online consumer awareness of legislation on consumer rights has a positive influence on the sustainable purchasing decision.

Stepping forward, online consumer engagement by means of an active response to detriment, namely the appeal to redress mechanisms, has been acknowledged as the underpinning of sustainable purchasing decisions in many studies [31,32,41,42]. "Being able to recognize frauds or scams is fundamental to consumer empowerment, not only to avoid detriment, but to report the problem and, possibly, to obtain redress" [32] (p. 8). Furthermore, sustainable purchasing decision-making is an expression of empowered consumers who share knowledge on their purchase experiences within specialized online communities, therefore rewarding vendors' professionalism and sanctioning deceptive practices (p. 11). Therefore, we presume that:

Hypothesis 6. Online consumer engagement has a positive influence on the sustainable purchasing decision. 
Focusing on Millennials, Euromonitor International's Global Consumer Trends Survey, conducted in 2016, concluded that " $53 \%$ of all respondents across all countries felt they could make a difference to the world through their choices and actions". Millennials were the most optimistic, having a strong belief in their ability to make an impact. They believe in their potential as change-making consumers, thus, in driving positive change and in giving back to the community [52].

By corroborating the aforementioned relationships between constructs (H1 to H6) into a final assumption, we presume that:

Hypothesis 7. Competition in the online marketplace has a positive influence on the sustainable purchasing decision.

All in all, based on the theoretical developments and hypotheses described, this study advances the following research model (Figure 1):

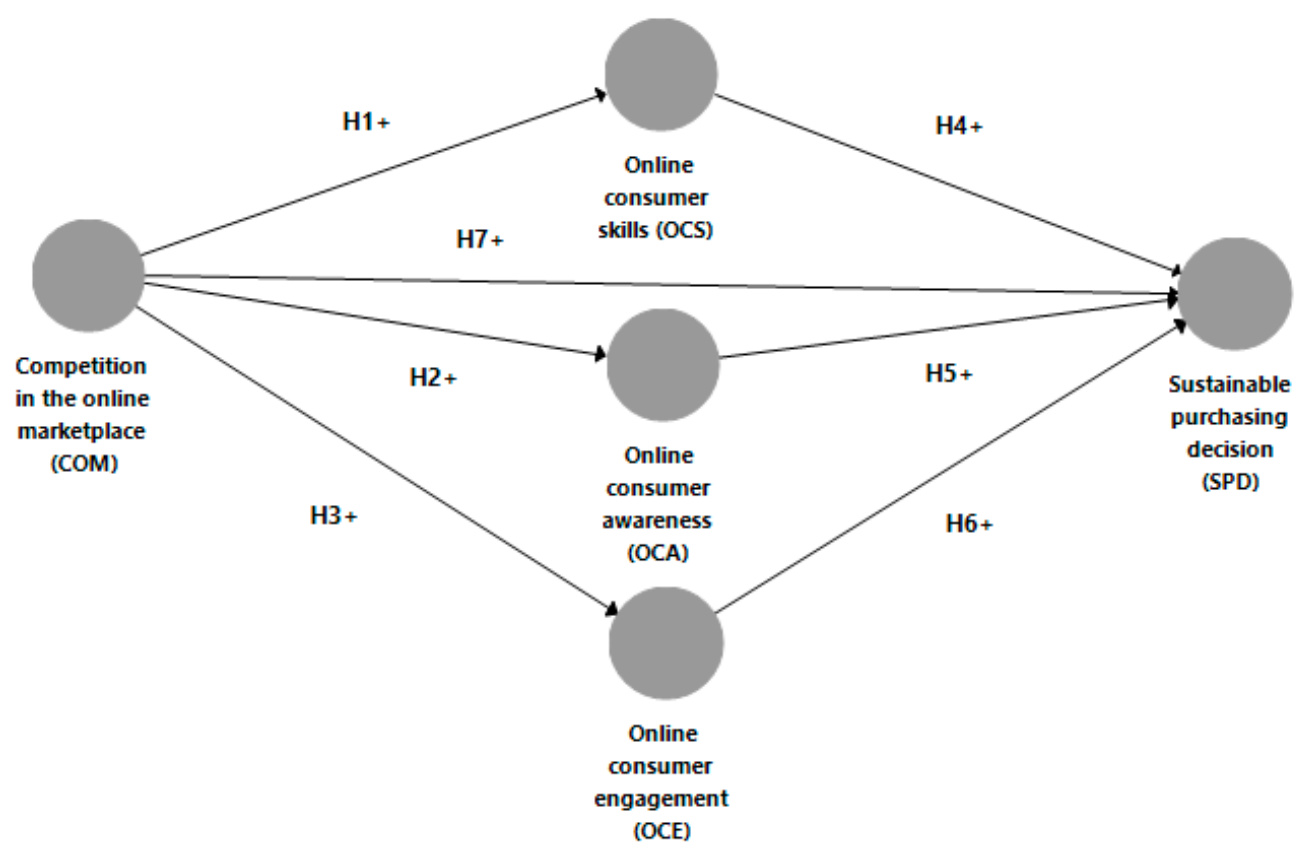

Figure 1. Research model with hypotheses.

\section{Materials and Methods}

\subsection{Data Collection and Sample}

A questionnaire-based survey was conducted with 318 college students from an Italian university, a representative population of the new Millennials generation. Subjects were invited to take part in a survey regarding online consumption and purchasing decisions by filling out an online form. The investigation unfolded between 14 February and 10 March 2017.

Upon acceptance, the participants completed a self-administered questionnaire comprising closed-ended questions. The constructs consisted of multiple items, measured on a five-point Likert scale which ranged from "strongly disagree" (1) to "strongly agree" (5) $(2=$ disagree, $3=$ neither disagree, nor agree, $4=$ agree).

\subsection{Measures}

The questionnaire items addressed five main areas, discussed previously, related to participants' activity in terms of online consumption; namely online consumer skills, awareness and engagement issues, competition in the online market place and online purchasing decisions. Questions falling 
into the first three categories are in line with the Consumer Empowerment Index advanced by Nardo et al. [24], the European Commission [32] and the OECD [38,39], which was further adapted to the specifics of the digital economy. In this vein, 25 items were developed. Most of the indicators for each dimension were illustrative of prior measurement scales employed in the testing of online consumption (as mentioned in Table 1). Both exogenous and endogenous variables of the research model were designed as subjective measures, relying on participants' self-reported insights.

Table 1. Constructs and items.

\begin{tabular}{|c|c|c|}
\hline Construct & Item & Sources \\
\hline \multirow{4}{*}{$\begin{array}{c}\text { Competition in the } \\
\text { online marketplace } \\
\text { (COM) } \\
\text { (Formative) }\end{array}$} & $\begin{array}{l}\text { COM1. Firms providing the same/similar products online offer } \\
\text { similar prices. }\end{array}$ & [34-40] \\
\hline & $\begin{array}{l}\text { COM2. Firms providing the same/similar products online offer similar } \\
\text { qualitative characteristics. }\end{array}$ & [34-40] \\
\hline & $\begin{array}{l}\text { COM3. Firms providing the same/similar products online use similar } \\
\text { user-friendly interfaces (the buying process is intuitive). }\end{array}$ & [34-40] \\
\hline & $\begin{array}{l}\text { COM4. Firms providing the same/similar products online offer } \\
\text { relevant and detailed information on the products on their websites. }\end{array}$ & [34-40] \\
\hline \multirow{5}{*}{$\begin{array}{c}\text { Online } \\
\text { consumer skills } \\
(\mathrm{OCS}) \\
\text { (Formative) }\end{array}$} & $\begin{array}{l}\text { OCS1. I use to compare offers and check where I can buy online the } \\
\text { cheapest desired product. }\end{array}$ & {$[12,15,24,32,38,40,41,52,53]$} \\
\hline & $\begin{array}{l}\text { OCS2. I use to check if there are any sales or promotions online } \\
\text { regarding the desired product. }\end{array}$ & {$[18,26,27,32,38,40,41]$} \\
\hline & $\begin{array}{l}\text { OCS3. I use to talk to the customer service assistant about additional } \\
\text { product details when I buy products online. }\end{array}$ & {$[24,27]$} \\
\hline & $\begin{array}{l}\text { OCS4. I use to read other customers' online reviews regarding their } \\
\text { experience in buying from a certain website before acting }\end{array}$ & {$[26,27,30,32,38,40,41,52,53]$} \\
\hline & $\begin{array}{l}\text { OCS5. I use to perform cost-benefit analyses before buying } \\
\text { products online. }\end{array}$ & {$[30,32,38,40,41,52,53]$} \\
\hline \multirow{8}{*}{$\begin{array}{l}\text { Online } \\
\text { consumer } \\
\text { awareness } \\
\text { (OCA) } \\
\text { (Reflective) }\end{array}$} & OCA1. I am aware of my consumers' rights when I buy on sales online. & {$[11,15,24,38,39,41,58-60]$} \\
\hline & $\begin{array}{l}\text { OCA2. I am aware of my consumers' rights when I buy online or in } \\
\text { mail order. }\end{array}$ & {$[11,15,24]$} \\
\hline & $\begin{array}{l}\text { OCA3. I am aware of the agencies (government and voluntary) offering } \\
\text { consumers guidance. }\end{array}$ & {$[24,38,39,41,50]$} \\
\hline & $\begin{array}{l}\text { OCA4. I am aware of the legal action of governmental and } \\
\text { non-governmental institutions on protecting consumers. }\end{array}$ & {$[1,24,38,39,41,50]$} \\
\hline & OCA5. I am aware of consumers' guarantee rights. & {$[11,15,24,50]$} \\
\hline & OCA6. I am aware of consumers' distance-purchasing rights. & {$[24,38,39,41,58-60]$} \\
\hline & $\begin{array}{l}\text { OCA7. I am aware of different sources of information about } \\
\text { consumer affairs. }\end{array}$ & {$[24,38,39,41,58-60]$} \\
\hline & $\begin{array}{l}\text { OCA8. I am aware of the existence of lots of consumer online } \\
\text { communities debating on consumers policies. }\end{array}$ & {$[24,26-28,39,41,58-60]$} \\
\hline \multirow{3}{*}{$\begin{array}{c}\text { Online consumer } \\
\text { engagement } \\
\text { (OCE) } \\
\text { (Reflective) }\end{array}$} & $\begin{array}{l}\text { OCE1. I gave a poor quality product back to the online seller and } \\
\text { demand money refund. }\end{array}$ & {$[24,27,42-46,52]$} \\
\hline & $\begin{array}{l}\text { OCE2. I demanded replacement of a poor quality product bought } \\
\text { online for a good one. }\end{array}$ & {$[24,27,42-46,52]$} \\
\hline & $\begin{array}{l}\text { OCE3. I gave a poor quality product back to the manufacturer for repair } \\
\text { (production plant/factory) on the basis of the warranty card. }\end{array}$ & {$[24,27,52]$} \\
\hline \multirow{5}{*}{$\begin{array}{l}\text { Sustainable } \\
\text { purchasing decision } \\
\text { (SPD) } \\
\text { (Reflective) }\end{array}$} & SPD1. I often buy products online. & {$[32,52,53]$} \\
\hline & $\begin{array}{l}\text { SPD2. I buy products online because online shops are more controlled } \\
\text { by the authorities in the field of consumer protection. }\end{array}$ & {$[14,32,43-46,50,52,53]$} \\
\hline & $\begin{array}{l}\text { SPD3. I buy products online because I can compare and contrast offers } \\
\text { against various product specifications. }\end{array}$ & {$[32,43-46,52,53]$} \\
\hline & $\begin{array}{l}\text { SPD4. I buy products online because I can carefully compare products } \\
\text { in terms of quality and sustainability. }\end{array}$ & {$[32,43-46,52,53]$} \\
\hline & $\begin{array}{l}\text { SPD5. I buy products online because I trust in the other customers' } \\
\text { experiences and reviews. }\end{array}$ & {$[32,43-48,52,53]$} \\
\hline
\end{tabular}

A final section addressed the respondents' characteristics in terms of gender, age, level of education and their experience in online consumption measured by means of the period of time 
they have been purchasing online and through the number of online providers they have purchased from). A synopsis in this respect is presented in Table 2.

Table 2. The profile of respondents.

\begin{tabular}{|c|c|c|c|c|}
\hline & Frequency & Percentage & Mean & Std. Deviation \\
\hline Age & - & - & 23.08 & 4.55 \\
\hline \multicolumn{5}{|c|}{ Gender } \\
\hline Females & 183 & $57.5 \%$ & - & - \\
\hline Males & 135 & $42.5 \%$ & - & - \\
\hline \multicolumn{5}{|c|}{ Level of education } \\
\hline Undergraduate & 210 & $66 \%$ & - & - \\
\hline Graduate & 108 & $34 \%$ & - & - \\
\hline \multicolumn{5}{|c|}{ Experience in online purchasing (years) } \\
\hline Less than a year ago & 38 & $11.9 \%$ & - & - \\
\hline Between 1 and 3 years ago & 111 & $34.9 \%$ & - & - \\
\hline Between 3 and 5 years ago & 94 & $29.6 \%$ & - & - \\
\hline More than 5 years ago & 75 & $23.6 \%$ & - & - \\
\hline \multicolumn{5}{|c|}{ Number of online providers } \\
\hline Less than 3 online sellers & 101 & $31.8 \%$ & - & - \\
\hline Between 3 and 7 online sellers & 151 & $47.4 \%$ & - & - \\
\hline More than 7 online sellers & 66 & $20.8 \%$ & - & - \\
\hline
\end{tabular}

\subsection{Measurement and Structural Model Assessment}

In order to properly assess the measurement and structural model, a component-based partial least squares (PLS) analysis was performed. The choice for a variance-based technique was supported in the framework of an exploratory endeavour and of a research model integrating both formative and reflective factors, pursuant to Hair, Ringle and Sarstedt [73] and Henseler et al. [74]. The structural equation modeling (SEM) technique was performed by means of SmartPLS Version 3 (SmartPLS $\mathrm{GmbH}$, Bönningstedt, Germany), a statistical tool which is currently considered in a myriad of studies from behavioral sciences.

The model goodness-of-fit ( $\mathrm{GoF})$ was examined taking into consideration the Euclidean distance between the model-implied and the empirical correlation matrix, that is, the standardized root mean square residual indicator (SRMR). The indicator mentioned was coined by Hu and Bentler [75] and then validated by Henseler et al. [76] as the most adequate GoF estimation for PLS path modeling. In the case of the current research model, the value of SRMR (i.e., 0.072) was below the recommended threshold of 0.08 , consequently supporting the model's GoF.

The psychometric properties of the constructs (presented in Table 3) were analysed according to Barclay, Higgins and Thompson's guidelines [77], which involve the testing of the convergent validity and discriminant validity of the measurement model.

On this front, the convergent validity was appraised by taking into account the factor loadings and cross-loadings in the case of the reflective constructs, average variance extracted (AVE), composite reliability (CR) and reliability (Cronbach alpha and rho_alpha) (as illustrated in Tables 3 and 4). The factor loadings of each indicator were greater than 0.65 and the AVE values were higher than the 0.60 threshold. Composite reliability assessment was also performed as it is given credit to be more accurate than Cronbach alpha [78,79]. However, Cronbach's alpha values of all indicators were above 0.6 while the reflective construct measure loadings exceeded the 0.70 level for composite reliability, thus, conforming to the criteria established by Yi and Davis [80]. As presented in Table 3, CR values varied from 0.88 to 0.92 while AVE varied from 0.59 to 0.73 . 
Table 3. Psychometric properties of reflective constructs.

\begin{tabular}{|c|c|c|c|c|c|c|c|}
\hline Construct & CR & $\begin{array}{c}\text { Cronbach } \\
\text { Alpha }\end{array}$ & Rho_Alpha & AVE & Indicator & $\begin{array}{c}\text { Weight } \\
\text { (Formative) }\end{array}$ & $\begin{array}{l}\text { Loading } \\
\text { (Reflective) }\end{array}$ \\
\hline \multirow{4}{*}{$\begin{array}{c}\text { COM } \\
\text { (Formative) }\end{array}$} & \multirow{4}{*}{-} & \multirow{4}{*}{-} & \multirow{4}{*}{1} & \multirow{4}{*}{-} & COM1 & 0.680 & \multirow{4}{*}{-} \\
\hline & & & & & COM2 & 0.588 & \\
\hline & & & & & $\mathrm{COM} 3$ & 0.540 & \\
\hline & & & & & COM4 & 0.785 & \\
\hline \multirow{5}{*}{$\begin{array}{c}\text { OCS } \\
\text { (Formative) }\end{array}$} & \multirow{5}{*}{ - } & \multirow{5}{*}{-} & \multirow{5}{*}{1} & \multirow{5}{*}{ - } & OCS1 & 0.588 & \multirow{5}{*}{-} \\
\hline & & & & & OCS2 & 0.666 & \\
\hline & & & & & OCS3 & 0.488 & \\
\hline & & & & & OCS4 & 0.761 & \\
\hline & & & & & OCS5 & 0.566 & \\
\hline \multirow{8}{*}{$\begin{array}{c}\text { OCA } \\
\text { (Reflective) }\end{array}$} & \multirow{8}{*}{0.92} & \multirow{8}{*}{0.90} & \multirow{8}{*}{0.91} & \multirow{8}{*}{0.59} & OCA1 & \multirow{8}{*}{-} & 0.795 \\
\hline & & & & & OCA2 & & 0.813 \\
\hline & & & & & OCA3 & & 0.732 \\
\hline & & & & & OCA4 & & 0.753 \\
\hline & & & & & OCA5 & & 0.762 \\
\hline & & & & & OCA6 & & 0.801 \\
\hline & & & & & OCA7 & & 0.781 \\
\hline & & & & & OCA8 & & 0.716 \\
\hline \multirow{3}{*}{$\begin{array}{c}\text { OCE } \\
\text { (Reflective) }\end{array}$} & \multirow{3}{*}{0.89} & \multirow{3}{*}{0.81} & \multirow{3}{*}{0.83} & \multirow{3}{*}{0.73} & OCE1 & \multirow{3}{*}{-} & 0.850 \\
\hline & & & & & OCE2 & & 0.911 \\
\hline & & & & & OCE3 & & 0.794 \\
\hline \multirow{5}{*}{$\begin{array}{c}\text { SPD } \\
\text { (Reflective) }\end{array}$} & \multirow{5}{*}{0.88} & \multirow{5}{*}{0.83} & \multirow{5}{*}{0.84} & \multirow{5}{*}{0.60} & SPD1 & \multirow{5}{*}{-} & 0.778 \\
\hline & & & & & SPD2 & & 0.786 \\
\hline & & & & & SPD3 & & 0.830 \\
\hline & & & & & SPD4 & & 0.791 \\
\hline & & & & & SPD5 & & 0.703 \\
\hline
\end{tabular}

Table 4. Cross loadings.

\begin{tabular}{cccc}
\hline Reflective Variables & OCA & OCE & SPD \\
\hline OCA1 & 0.795 & 0.251 & 0.279 \\
OCA2 & 0.813 & 0.280 & 0.267 \\
OCA3 & 0.732 & 0.272 & 0.144 \\
OCA4 & 0.753 & 0.229 & 0.126 \\
OCA5 & 0.762 & 0.229 & 0.213 \\
OCA6 & 0.801 & 0.250 & 0.149 \\
OCA7 & 0.781 & 0.323 & 0.141 \\
OCA8 & 0.716 & 0.244 & 0.178 \\
OCE1 & 0.278 & 0.850 & 0.248 \\
OCE2 & 0.321 & 0.911 & 0.210 \\
OCE3 & 0.258 & 0.794 & 0.182 \\
SPD1 & 0.235 & 0.239 & 0.778 \\
SPD2 & 0.230 & 0.239 & 0.786 \\
SPD3 & 0.178 & 0.149 & 0.830 \\
SPD4 & 0.160 & 0.227 & 0.791 \\
SPD5 & 0.204 & 0.131 & 0.703 \\
\hline
\end{tabular}

The discriminant validity of the measurement model was examined by means of comparing the square roots of the AVEs with other correlation scores in the correlation matrix (as illustrated in Table 5). The values analysis confirmed that none of the construct correlations (non-diagonal entries) was above the corresponding square root of AVE (diagonal entries). At this level, the data met the 
guidelines mentioned by Fornell and Larcker [81], thus supporting the discriminant validity and the reliability adequacy of the overall measurement items.

Table 5. Discriminant validity of measurement model.

\begin{tabular}{cccccc}
\hline & OCA & OCE & OCS & COM & SPD \\
\hline OCA & 0.770 & & & & \\
OCE & 0.336 & 0.853 & & & \\
OCS & 0.208 & 0.255 & & & \\
COM & 0.242 & 0.147 & 0.128 & & \\
SPD & 0.255 & 0.253 & 0.456 & 0.111 & 0.779 \\
\hline
\end{tabular}

Diagonals stand for the square root of the average variance extracted while the off-diagonals are correlations among constructs.

Focusing on Diamantopoulos and Siguaw's [82] criteria on the usage of the variance inflation factor (VIF) for multicollinearity testing, we further computed the VIF values. The results provided evidence that all the VIF scores were below the 3.3 threshold (ranging from 1.03 to 2.54), indicating the absence of multicollinearity among constructs.

The structural model was also assessed in accordance with Hair et al.'s criteria [83], which involved the computation of $R^{2}$, beta and $t$-values. The bootstrapping procedure with 5000 resamples brought about the effect sizes $\left(f^{2}\right)$ while the blindfolding procedure engendered the predictive relevance $\left(Q^{2}\right)$ configurations (Table 6).

Table 6. Results of the structural model analysis (hypotheses testing).

\begin{tabular}{|c|c|c|c|c|c|c|c|c|}
\hline Hypothesis & Relationship & Std. Beta & Std. Dev. & $t$-Value & Decision & $R^{2}$ & $f^{2}$ & $Q^{2}$ \\
\hline H1 & COM $->$ OCS & 0.128 & 0.129 & 0.988 & Not supported & 0.016 & 0.017 & 0.003 \\
\hline $\mathrm{H} 2$ & COM $->$ OCA & 0.242 & 0.099 & $2.447 *$ & Supported & 0.059 & 0.062 & 0.030 \\
\hline H3 & $\mathrm{COM}->\mathrm{OCE}$ & 0.147 & 0.076 & 1.924 & Not supported & 0.022 & 0.022 & 0.011 \\
\hline $\mathrm{H} 4$ & OCS -> SPD & 0.400 & 0.063 & $6.356^{* *}$ & Supported & - & 0.194 & - \\
\hline H5 & OCA $->$ SPD & 0.134 & 0.062 & $2.165 *$ & Supported & - & 0.020 & - \\
\hline H6 & OCE -> SPD & 0.104 & 0.058 & 1.802 & Not supported & - & 0.012 & - \\
\hline H7 & COM $->$ SPD & 0.013 & 0.057 & 0.222 & Not supported & - & 0.000 & - \\
\hline $\begin{array}{l}\text { Overall } \\
\text { model }\end{array}$ & $\begin{array}{c}\text { COM }->\text { OCS, OCA, } \\
\text { OCE -> SPD }\end{array}$ & - & - & - & 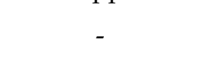 & 0.244 & - & 0.129 \\
\hline
\end{tabular}

As indicated in the table above, the $R^{2}$ value was 0.244 , suggesting a good model [83]. The bootstrapping procedure allowed the computation of the change in $R^{2}$ in case a specific exogenous dimension was extracted from the research model. In line with Cohen's [84] parameters, three out of seven relationships indicated small effect sizes (above 0.02 ).

The measurement of the predictive relevance was ensured by the multi-item endogenous reflective variable which also ensured a blindfolding procedure to be performed. As illustrated in Table 6, two out of the four relationships indicated a small (0.03) and a medium-to-large predictive relevance (0.129), as Hair et al. [83] posit.

\section{Results}

The results of the PLS structural model are presented in Figure 2. In the case of the Italian college students who participated in the survey, the model accounts for almost $25 \%$ of variance in sustainable purchasing decision. 


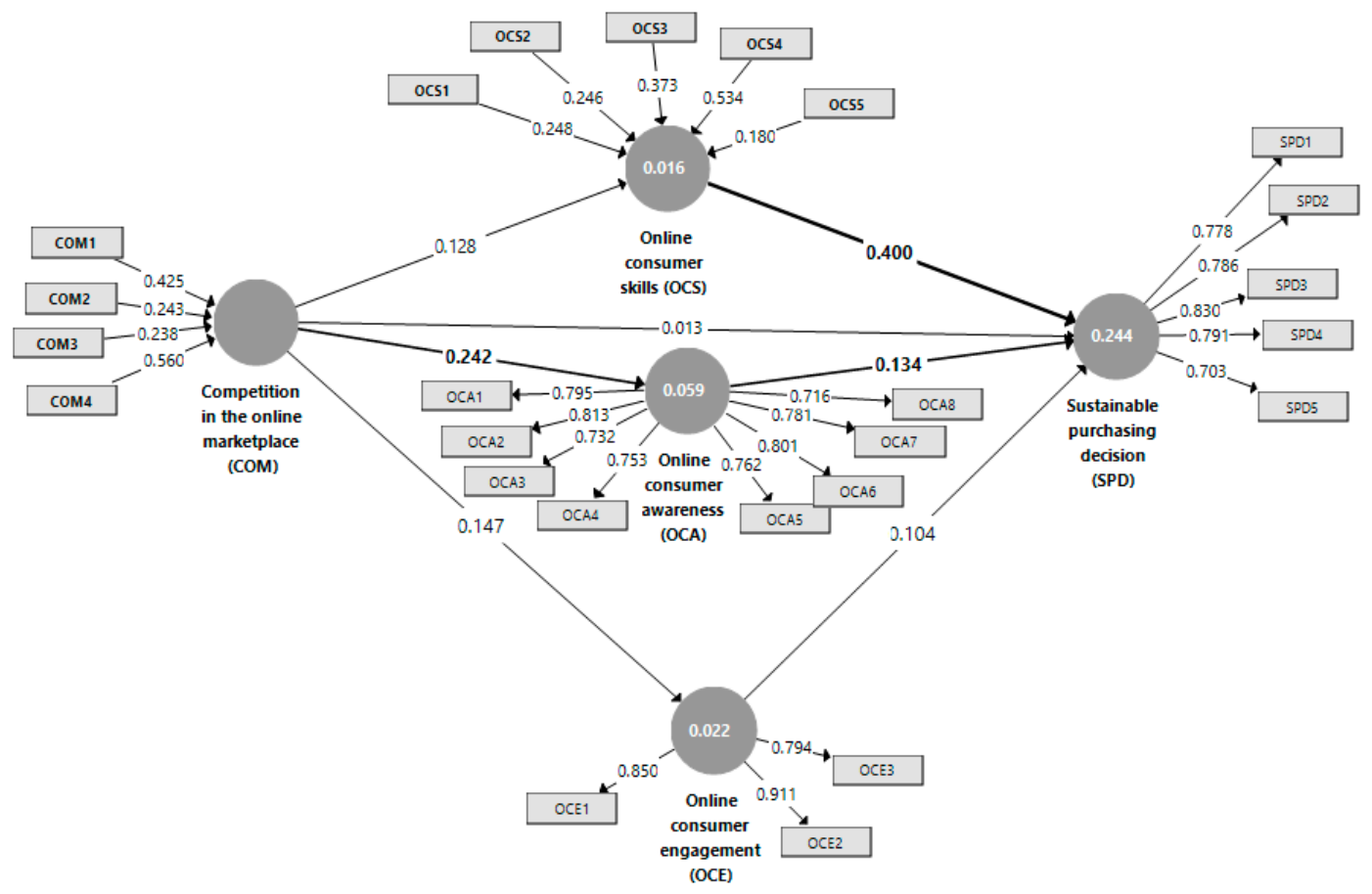

Figure 2. Partial least squares (PLS) test of the proposed structural model.

As presented in Figure 2, competition in the online market place has no significant influence on the development of online consumer skills $(p>0.05)$, thus, not supporting Hypothesis 1 . The situation is similar in the case of the relationship between competition in the online marketplace and online consumer engagement given the fact that the former construct does not exert a significant positive influence on the latter $(p>0.05)$. That being the case, Hypothesis 3 is also rejected. A different pattern is met in the relationship between competition in the online marketplace and awareness of the legislation on consumer rights $(\beta=0.242, p<0.05)$. The investigation supported Hypothesis 2 , providing evidence that the level of awareness is positively influenced by competition among online providers.

Focusing on the relationship between online consumer skills and sustainable purchasing decisions, the results indicated the highest significant positive influence among the model constructs $(\beta=0.400$, $p<0.001)$, hence, conforming Hypothesis 4 . Similarly, but to a smaller extent, the online consumer awareness of legislation on consumer rights exerts a significant positive influence on the sustainable purchasing decision $(\beta=0.134, p<0.05)$, supporting Hypothesis 5 .

Although online consumer engagement plays an important role in the equation of the sustainable purchasing decision, the present research has not brought forward a significant relationship between the two constructs $(p>0.05)$. Consequently, Hypothesis 6 was not supported in the framework of this study. Likewise, the data did not confirm the existence of a significant direct and positive influence of competition in the online marketplace on the sustainable purchasing decision $(p>0.05)$. This triggers the rejection of Hypothesis 7, as well.

To conclude, three out of the seven hypotheses were supported in the phenomenological context of a sample comprising Italian college students.

\section{Discussion}

\subsection{Research Contribution and Originality: Theoretical and Practical Implications}

The present paper aimed at developing a research model integrating the dynamics of the digital economy, in general, and of competition in the online market place, in particular, and the sustainable purchasing decision. The model presumed the existence of three main relationship mediators, namely 
online consumer skills, online consumer awareness and online consumer engagement. On this front, the model accounts for almost $25 \%$ of the variance in sustainable purchasing decisions.

As previously depicted, three out of the seven hypotheses formulated were supported in the context of the population investigated. In support of Hypothesis 2, the empirical analysis brought evidence of a significant positive relationship between competition in the online market place (i.e., multiple firms offering similar products in terms of prices, qualitative characteristics, buying process and specifications) and online consumer awareness (i.e., awareness of consumers' rights when buying on sales, of the agencies offering consumers guidance, of the legal action of governmental and non-governmental institutions on protecting consumers, of consumers' guaranteed rights, of consumers' distance-purchasing rights, of different sources of information about consumer affairs, of many online communities debating consumer policy). The evidence is in line with previous studies on the topic $[15,24,58-60]$ which have drawn upon the emerging business models within the digital economy and on the subsequent substantive shift in people's attitudes and conduct. In this vein, new issues have been raised regarding consumer protection $[38,39]$ and, thus, regarding the imperative to be aware of the legislation on consumer rights $[15,24,41]$.

Focusing on the relationship between online consumer skills (i.e., comparing offers, checking sales or promotions, consulting the customer service assistant about additional product details, reading other customers' online reviews, performing cost-benefit analyses before buying products online) and the sustainable purchasing decision (i.e., buying products online: because online shops are more controlled by the authorities, because of the opportunity to compare and contrast offers against various product specifications and against quality and sustainability criteria, to use other customers' experiences and reviews), the findings confirmed the existence of a significant positive influence, the highest within the research model (Hypothesis 4). The results are consistent with the specialized literature in the field which posits that a new generation of empowered consumers is able to drive a positive social change by means of education, access to relevant information and capacity to assess information correctly [38,52,53], thus making optimal and sustainable decisions [26,27,32]. At this level, the college students questioned - who are representative of the Millennials generation-are a point of reference in promoting socially responsible views on consumption and in adhering to a sustainability framework in their general orientation $[53,55]$.

In its own right, the investigation of the relationship between online consumer awareness of legislation on consumer rights and the sustainable purchasing decision supported the existence of a significant positive influence between the two constructs, thus confirming Hypothesis 5 . The findings are in line with the theoretical standpoints underlined in the literature review $[24,50,52]$ and acknowledge that consumer awareness constitutes an important prerequisite of responsible consumption, a milestone in the study of the Millennials generation [52,53].

As previously shown, online consumer engagement (i.e., the return of a poor quality product to the online seller and demand of a refund, the demand to replace a poor quality product bought online for a good one, the return of a poor quality product to the manufacturer on the basis of the warranty card) does not exert any influence on the sustainable purchasing decision in the case of the college students questioned. The findings do not confirm the evidence supplied by other studies on the topic $[23,27,42-46,52]$. A possible explanation on this front may refer to the narrower scope of the consumer engagement construct, which only addressed the actual behavior when touching on problems for which there is a legitimate cause for complaint.

By corroborating the aforementioned empirical results, the present study had a twofold contribution to the extant literature. To start with, to the best of our knowledge, the relationship between the digital economy, in general, and competition in the online marketplace, in particular, and the sustainable purchasing decision has been scarcely discussed in the case of Millennials. Moreover, a phenomenological investigation within the European Union (i.e., Italy) was yet to be conducted. Even though the findings are country-specific (lacking statistical representativeness at the European level), they may be treated as a reference point when conducting similar research, all the more so as 
the OECD's report [33] — based on a survey conducted in seven European countries—suggested that young people tend to embrace a rather generation-centric sustainable orientation than a nation-based approach. This pattern may be interpreted in the light of the similar effects catalysed by EU integration and globalization processes, in terms of media access and the exposure of Millennials at a global scale. Moreover, pursuant to the OECD's policies [33,38,39], many European countries have been implementing sustainable consumption programmes and courses as part of a more general consumer education in universities, thus ensuring cross-national awareness and engagement in the case of students.

Secondly, the study relied on the exploration of online consumers' sustainable purchasing decisions by employing a relevant and novel statistical procedure, that is, the structural equation modeling based on partial least squares. The usage of PLS-SEM in the testing, measurement and assessment of the research model supported the proper identification of the extant effects and the explanation of variance within an exploratory framework.

From a more practical perspective, the current findings are indicative of the new business models which should be effectively capitalized on by online providers in order to preserve their performance. As new generations of online consumers emerge with a clear focus on sustainable, ethical, long-lasting and feasible products, on responsible consumption and rational decision-making, organizations competing in the online marketplace should attach greater importance to adjusting to the topical market conditions.

In this framework, the current study reveals major challenges for online providers. Firstly, vendors should better understand the contexts in which consumers exercise their choices, rationale and emotions. Firms are, thus, pushed towards the employment of a wide range of qualitative and quantitative research techniques to assess consumers' need for empowerment and sustainable consumption. Secondly, preserving the competitive advantage in the fiercely-augmented competition of the digital marketplace requires leading-edge strategies, integrating both tangible and intangible factors to foresee and keep pace with consumers' expectations related to sustainable purchasing. Furthermore, online providers are challenged to get rid of the linear thinking business models which were mainly focused on keeping up with the competitors and concentrate on multidimensional consumer specificity, especially on improved online consumer skills and awareness, as $\mathrm{H} 2, \mathrm{H} 4$ and $\mathrm{H} 5$ confirmed.

This challenge is much more imperative in the case of Millennials. As the recent survey conducted in 2016 by Kearney [72] with 149 Millennials reveals, their purchasing attitudes toward products and brands are intrinsically grounded in sustainability. Millennials show an increasing propensity to be loyal to products and brands they can personally use to live sustainable lives. They represent a new market segment steadily growing its influence in the digital marketplace. As a consequence, companies have to adapt processes, practices and value propositions to make their products sustainable, in order to seize the opportunities created.

\subsection{Limitations and Future Research Directions}

As with any other research, the present study would benefit from further improvements.

On the one hand, the conceptual model may be enriched in terms of scope through the inclusion of other constructs (i.e., consumer experience, consumer knowledge sharing, etc.). On this point, a future study envisioning other multi-item factors would provide a more thorough insight into online marketplace dynamics. Additionally, future studies may go deeper into refining relationships among the proposed concepts, for example, by testing mutual interactions among the online consumer skills, awareness and engagement constructs.

On the other hand, the investigation of the advanced hypotheses with larger samples or in the case of other populations would expand the analysis, offering a more accurate perspective and ensuring multiple-context comparisons. For example, replication of the survey using similar samples from other countries in Europe or elsewhere would provide further evidence on the relationships inferred, for both the supported and rejected hypotheses. In this vein, conducting confirmatory examinations would generate compelling insights in terms of debunking effects and testing model fit. 
Supplementary Materials: The following are available online at www.mdpi.com/2071-1050/9/5/683/s1: The survey database in Excel format.

Acknowledgments: No grants were used for the research and publication of the article. Only personal funds were employed.

Author Contributions: Patrizia Gazzola, Gianluca Colombo and Roberta Pezzetti reviewed the literature, conducted the survey, analyzed the data, discussed the implications of the results and performed the article revision. Luminița Nicolescu designed the questionnaire items and developed the methodological and empirical sections.

Conflicts of Interest: The authors declare no conflict of interest.

\section{References}

1. Van Gorp, N.; Batura, O. Challenges for Competition Policy in A Digitalised Economy. 2015. Available online: http:/ /www.europarl.europa.eu/RegData/etudes/STUD/2015/542235/IPOL_STU(2015) 542235_EN.pdf (accessed on 14 November 2016).

2. Vătămănescu, E.M.; Andrei, A.G.; Leovaridis, C.; Dumitriu, D.L. Exploring Network-Based Intellectual Capital as a Competitive Advantage: An Insight Into European Universities From Developing Economies. In Proceedings of the 7th European Conference on Intellectual Capital (ECIC 2015), Cartagena, Spain, 9-10 April 2015; Navarro, J.G.C., Ed.; Academic Conferences and Publishing International Limited: Reading, UK, 2015; pp. 350-358.

3. Alexandru, V. Global value chains from a multidimensional perspective. A preliminary insight. In Strategica. Opportunities and Risks in the Contemporary Business Environment; Brătianu, C., Zbuchea, A., Pînzaru, F., Leon, R.D., Vătămănescu, E.M., Eds.; Tritonic: Bucharest, Romania, 2016; pp. 324-331.

4. Monopolkomission. Competition Policy: the Challenge of Digital Markets. Available online: http://www. monopolkommission.de/images/PDF/SG/s68_fulltext_eng.pdf (accessed on 12 November 2016).

5. European Commission (EC). The Collaborative Economy Factsheet. Available online: http://ec.europa.eu/ DocsRoom/documents/16955/attachments/1/translations (accessed on 4 December 2016).

6. World Bank (WB). World Development Report 2016: Digital Dividends. Available online: http:/ /www-wds.worldbank.org/external/default/WDSContentServer/WDSP/IB/2016/01/13/ 090224b08405ea05/2_0/Rendered/PDF/World0developm0000digital0dividends.pdf (accessed on 7 October 2016).

7. Zbuchea, A.; Vătămănescu, E.M.; Pînzaru, F. M-commerce-Facts and Forecasts. A Comparative Analysis within a Triad Framework: India, Romania, and the United States. Manag. Dyn. Know. Econ. 2016, 4, 387-408.

8. Hapenciuc, C.V.; Pînzaru, F.; Vătămănescu, E.M.; Stanciu, P. Converging Sustainable Entrepreneurship and the Contemporary Marketing Practices. An Insight into Romanian Start-Ups. Amfiteatru Econ. 2015, 17, 938-954.

9. Dincă, V.M. Privatization of Water. Available online: http://www.jsde.ro/wp-content/uploads/2015/06/ PRIVATISATION-OF-WATER-DINCA-Violeta-Mihaela.pdf (accessed on 6 February 2017).

10. Pînzaru, F. Marketing: It's all about digital. In Strategica. Local versus Global; Brătianu, C., Zbuchea, A., Pînzaru, F., Leon, R.D., Vătămănescu, E.M., Eds.; Tritonic: Bucharest, Romania, 2015; pp. 751-754.

11. Prensky, M. Digital Natives, Digital Immigrant. Available online: http://www.marcprensky.com/ writing/Prensky\%20-\%20Digital\%20Natives,\%20Digital\%20Immigrants\%20-\%20Part1.pdf (accessed on 24 November 2016).

12. Simões, F.D. Consumer behavior and sustainable development in China: The role of behavioral sciences in environmental policymaking. Sustainability 2016, 8, 897. [CrossRef]

13. Andrei, A.G.; Zait, A.; Vătămănescu, E.M.; Pînzaru, F. Word of mouth generation and brand communication strategy: Findings from an experimental study explored with PLS-SEM. Ind. Manag. Data Sys. 2017, 117, 478-495. [CrossRef]

14. Andrei, A.G.; Zait, A. Branding insights: An interdisciplinary journey from perception to action. In Strategica. Management, Finance, and Ethics; Brătianu, C., Zbuchea, A., Pînzaru, F., Vătămănescu, E.M., Eds.; Tritonic: Bucharest, Romania, 2014; pp. 593-604. 
15. Kerber, W. Digital Markets, Data, and Privacy: Competition Law, Consumer Law, and Data Protection. Available online: https:/ /www.uni-marburg.de/fb02/makro/forschung/magkspapers/paper_2016/142016_kerber.pdf (accessed on 14 November 2016).

16. Consumers International (CI). State of Consumer Protection Survey 2014/15 Summary. 2014. Available online: www.consumersinternational.org/media/.../ci-survey-summary-2015-english.pdf (accessed on 14 October 2016).

17. Organisation for Economic Co-operation and Development (OECD). The Interface between Competition and Consumer Policies. Available online: www.oecd.org/regreform/sectors/40898016.pdf (accessed on 14 November 2016).

18. Madill, J.; Mexis, A. Consumers at the Heart of EU Competition Policy. Available online: ec.europa.eu/ competition/publications/cpn/2009_1_7.pdf (accessed on 12 December 2016).

19. Erbach, G. EU and US Competition Policies. Similar Objectives, Different Approaches. Available online: http:/ / www.europarl.europa.eu/RegData/bibliotheque/briefing/2014/140779/LDM_BRI(2014) 140779_REV1_EN.pdf (accessed on 14 November 2016).

20. HM Government (HMG). Review of the Balance of Competences between the United Kingdom and the European Union. Competition and Consumer Policy Report. Available online: https://www.gov.uk/government/uploads/system/uploads/attachment_data/file/332779/Review_of_ the_Balance_of_Competences_between_the_United_Kingdom_and_the_European_Union.pdf (accessed on 18 September 2016).

21. European Commission (EC). Report on Competition Policy 2015. Available online: ec.europa.eu/ competition/publications/annual_report/2015/part1_en.pdf (accessed on 11 November 2016).

22. European Commission (EC). EU Competition Policy in Action: COMP in ACTION. Available online: ec.europa.eu/competition/publications/kd0216250enn.pdf (accessed on 27 November 2016).

23. Gutierrez, A.; Thornton, T.F. Can consumers understand sustainability through seafood eco-labels? A US and UK case study. Sustainability 2014, 6, 8195-8217. [CrossRef]

24. Nardo, M.; Loi, M.; Rosati, R.; Manca, A. The Consumer Empowerment Index. A Measure of Skills, Awareness and Engagement of European Consumers. Available online: http:/ /ec.europa.eu/consumers/ consumer_empowerment/docs/JRC_report_consumer_empowerment_en.pdf (accessed on 14 February 2016).

25. Andrei, A.G.; Iacob, A. From user's motivations to branding: The case of social networks. In Proceedings of the 4th International Conference on Globalization and Higher Education in Economics and Business Administration-GEBA 2010, Iasi, Romania, 21-23 October 2010; Airinei, D., Pintilescu, C., Asandului, M., Andries, A.M., Eds.; Alexandru Ioan Cuza University of Iasi Publishing House: Iasi, Romania, 2011; pp. 139-144.

26. The benefit of competition policy for consumers. In Proceedings of the United Nations Conference on Trade and Development (UNCTAD), Geneva, Switzerland, 8-10 July 2014.

27. Office of Competition and Consumer Protection (OCCP). Awareness of Consumer Rights and Analysis of Barriers Preventing Consumers from Safe and Satisfactory Participation in the Market. Available online: https: / / uokik.gov.pl/download.php?plik=8519 (accessed on 7 November 2016).

28. Vătămănescu, E.M.; Andrei, A.G.; Dumitriu, D.L.; Leovaridis, C. Harnessing network-based intellectual capital in online academic networks. From the organizational policies and practices towards competitiveness. J. Knowl. Manag. 2016, 20, 594-619. [CrossRef]

29. Bolisani, E.; Borgo, S.; Oltramari, A. Using knowledge as an object: Challenges and implications. Knowl. Manag. Res. Practi. 2012, 10, 202-205. [CrossRef]

30. Brătianu, C.; Bolisani, E. Knowledge strategy: an integrated approach for managing uncertainty. In Proceedings of the 16th European Conference on Knowledge Management, Udine, Italy, 3-4 September 2015; Massaro, M., Garlatti, A., Eds.; Academic Conferences and Publishing International Limited: Reading, UK, 2015; pp. 169-177.

31. Bolisani, E.; Scarso, E.; Zieba, M. How Small KIBS Companies Manage Their Intellectual Capital? Towards an Emergent KM Approach. In Proceedings of the 7th European Conference on Intellectual Capital (ECIC 2015), Cartagena, Spain, 9-10 April 2015; Cegarra Navarro, J.G., Ed.; Academic Conferences and Publishing International Limited: Reading, UK, 2015; pp. 25-33. 
32. European Commission. Commission Staff Working Paper. Consumer Empowerment in the EU. Available online: http:/ /ec.europa.eu/consumers/consumer_empowerment/docs/swd_consumer_empowerment_ eu_en.pdf (accessed on 10 April 2017).

33. Organisation for Economic Co-Operation and Development (OECD). Promoting Sustainable Consumption. Good Practices in OECD Countries. Available online: https://www.oecd.org/greengrowth/40317373.pdf (accessed on 9 April 2017).

34. Delp, A.B.; Mayo, J.W. The Evolution of "Competition": Lessons for 21st Century Telecommunications Policy. Rev. Ind. Organ. 2016. [CrossRef]

35. Fatas, E.; Lyons, B. Consumer Behaviour and Market Competition. In Behavioural Economics in Competition and Consumer Policy; Mehta, J., Ed.; ESRC Centre for Competition Policy: Norwich, UK, 2013; pp. 27-38.

36. Laitenberger, J. Staying Abreast of Digital Markets in the European Union: Taking a Closer Look at e-Commerce. In Proceedings of the Annual Conference on International Antitrust Law and Policy, New York, NY, USA, 22 September 2016; pp. 1-8.

37. Bauer, M.; Erixon, F. Competition, Growth and Regulatory Heterogeneity in Europe's Digital Economy. Available online: http:/ /ecipe.org/publications/competition-growth-and-regulatory-heterogeneity-ineuropes-digital-economy/ (accessed on 9 February 2017).).

38. Organisation for Economic Co-operation and Development (OECD). Consumer Education Policy Recommendations of the OECD'S Committee on Consumer Policy. Available online: http://www.oecd.org/ dataoecd/32/61/44110333.pdf (accessed on 9 April 2017).

39. Organisation for Economic Co-operation and Development (OECD). Consumer Protection in E-commerce: OECD Recommendation. Available online: http://www.oecd.org/sti/consumer/ECommerceRecommendation-2016.pdf (accessed on 9 April 2017).

40. Beranek, W.; Kamerschen, D.R. Consumers Are More Important Than Generally Believed. Available online: https://ncsu.edu/ffci/publications/2013/v18-n1-2013-spring/beranek-kamerschen.php (accessed on 10 April 2017).

41. Mwakatumbula, H.; Moshi, G.C.; Mitomo, H. Determinants of Consumers' Knowledge on their Rights in Telecommunication Markets: Case of Tanzania. Int. J. Manag. Public Sect. Inf. Commun. Technol. 2016, 7, 9-21. [CrossRef]

42. Bonchek, M.; Cornfield, G. Focus on Keeping up with Your Customers, Not Your Competitors. Available online: https://hbr.org/2016/04/focus-on-keeping-up-with-your-customers-not-your-competitors (accessed on 10 April 2017).

43. Case, S. Sustainable Purchasing 101: Tools for Buying Greener Products. Available online: http:/ / www.triplepundit.com/special/setting-the-standard/sustainable-purchasing-101-tools-buyinggreener-products/ (accessed on 10 April 2017).

44. Maher, M.; Reynolds, P.; Muysert, P.; Wandschneider, F. Resetting Competition Policy Frameworks for the Digital Ecosystem. Available online: http:/ /www.gsma.com/publicpolicy/wp-content/uploads/2016/10/ GSMA_Resetting-Competition_Report_Oct-2016_60pp_WEBv2.pdf (accessed on 10 February 2017).).

45. Păduraru, T.; Vătămănescu, E.M.; Andrei, A.G.; Pînzaru, F.; Zbuchea, A.; Maha, L.G.; Boldureanu, G. Sustainability in relationship marketing: An exploratory model for the industrial field. Environ. Eng. Manag. J. 2016, 15, 1635-1647.

46. Wright, L.T.; Newman, A.; Dennis, C. Enhancing Consumer Empowerment. Eurp. J. Mark. 2006, 40, 925-935. [CrossRef]

47. Case, S. Transparency and Certification: The Yin and Yang of Sustainability. Available online: http:/ / www.triplepundit.com/special/setting-the-standard/yin-yang-sustainability-communicationenvironmental-labels-environmental-product-declarations/ (accessed on 10 April 2017).

48. Newell, A. Two Years Later. Attitudes toward Green Are Looking Up. Available online: http://www. triplepundit.com/2013/10/attitudes-improved-years/ (accessed on 10 April 2017).

49. Vestager, M. e-Commerce: A Fair Deal for Consumers Online. Available online: https://ec.europa.eu/commission/ commissioners/2014-2019/vestager/announcements/e-commerce-fair-deal-consumers-online_en (accessed on 10 April 2017).

50. Vătămănescu, E.-M.; Nistoreanu, B.G.; Mitan, A. Competition and Consumer Behavior in the Context of the Digital Economy. Amfiteatru Econ. 2017, 19, 354-366. 
51. Gazzola, P.; Sepashvili, E.; Lo Parco, A. The road of sustainable development: Sustainable enterprises. In Proceeding of the 11th International Silk Road Conference on Innovations in Business, Education and Sciences, Tbilisi, Georgia, 20-21 May 2016; Ustunyer, I., Ed.; LLC International Black Sea University: Tbilisi, Georgia, 2016; pp. 63-68.

52. Euromonitor International. Global Changemakers: Real Market Impact of Empowered Consumers. 2017. Available online: http:/ / go.euromonitor.com/white-paper-industry-2016-Global-Changemakers-MarketImpact-Empowered-Consumers.html (accessed on 27 February 2017).

53. Pînzaru, F.; Vătămănescu, E.M.; Mitan, A.; Săvulescu, R.; Vițelar, A.; Noaghea, C.; Bălan, M. Millennials at Work: Investigating the Specificity of Generation Y versus Other Generations. Manag. Dyn. Knowl. Econ. 2016, 4, 173-192.

54. Sutherland, A.; Tompson, B. Kidfuence: The Marketer's Guide to Understanding and Reaching Generation Y-Kids, Tweens and Teens; McGraw Hill: New York, NY, USA, 2003.

55. Mitan, A. Do Romanian Youngsters Envision a CSR-Oriented World? A Research Regarding Digital Natives' Values. In Strategica. Management, Finance, and Ethics; Brătianu, C., Zbuchea, A., Pînzaru, F., Leon, R.D., Vătămănescu, E.M., Eds.; Tritonic: Bucharest, Romania, 2014; pp. 763-779.

56. Gazzola, P.; Pezzetti, P.; Pavione, P. Sustainable consumption in the luxury industry: Towards a new paradigm in the China's high-end demand? In Proceedings of the 2nd Czech-China Scientific Conference, Ostrava, Czech Republic, 7 June 2016; Gottvald, J., Praus, P., Eds.; InTech: Rijeka, Croatia, 2017; Chapter 12. [CrossRef]

57. Zhou, G.; Hu, W.; Huang, W. Are Consumers Willing to Pay More for Sustainable Products? A Study of Eco-Labeled Tuna Steak. Sustainability 2016, 8, 494. [CrossRef]

58. Pomarici, E.; Vecchio, R. Millennial generation attitudes to sustainable wine: An exploratory study on Italian consumers. J. Clean. Prod. 2014, 66, 537-545. [CrossRef]

59. Gurău, C. A life-stage analysis of consumer loyalty profile: Comparing Generation X and Millennial consumers. J. Consum. Mark. 2012, 29, 103-113. [CrossRef]

60. Gazzola, P.; Mella, P. Can CSR influence employees satisfaction? Ann. Univ. Oradea Econ. Sci. Ser. 2016, 25, 485-493.

61. Ordun, G. Millennial (Gen Y) consumer behavior their shopping preferences and perceptual maps associated with brand loyalty. Can. Soc. Sci. 2015, 11, 40-55.

62. Nielsen, N.V. The Nielsen Global Survey of Corporate Social Responsibility and Sustainability. Available online: http:/ / www.nielsen.com/it/it.html (accessed on 9 January 2017).

63. Lemee, A. Agents of Change: How Millennial Consumerism Drives Corporate Sustainability. Available online: http:/ / www.sustainablecap.com/featured-news/agents-of-change-how-millennial-consumerismdrives-corporate-sustainability/ (accessed on 30 October 2016).

64. Cheng, A. Fair Trade's Becomes a Fashion Trend. Available online: http://www.wsj.com/articles/fair-tradebecomes-a-fashion-trend-1436307440 (accessed on 6 November 2016).

65. Balsiger, P. The Fight for Ethical Fashion: The Origins and Interactions of the Clean Clothes Campaign; Routledge: New York, NY, USA, 2016.

66. Business Insider. How Important Is Sustainabilty to Millennials. An Emerging Retail Trend Is Key for Attracting Millennials. Available online: http:/ / www.businessinsider.com/how-important-is-sustainabilityto-millennials-2015-10?IR=T (accessed on 27 October 2015).

67. Hanks, K.; Odom, W.; Roedl, D.; Blevis, E. Sustainable Millennials: Attitudes towards Sustainability and the Material Effects of Interactive Technologies. In Proceedings of the SIGCHI Conference on Human Factors in Computing Systems, CHI 2008, Florence, Italy, 5-10 April 2008; ACM: New York, NY, USA, 2008; pp. 333-342.

68. Donnelly, C.; Scaff, R. Who Are The Millennial Shoppers? And What Do They Really Want? Available online:. Available online: https:/ / www.accenture.com/us-en/insight-outlook-who-are-millennial-shoppers-whatdo-they-really-want-retail (accessed on 18 January 2017).

69. Smith, K.T. Millennials' interpretations of green terminology. Acad. Mark. Stud. J. 2014, 18, 55-68.

70. Vătămănescu, E.M.; Pînzaru, F.; Andrei, A.G.; Zbuchea, A. Investigating SMEs sustainability with partial least squares structural equation modeling. Transform. Bus. Econ. 2016, 15, 259-273.

71. Soto-Acosta, P.; Cismaru, D.M.; Vătămănescu, E.M.; Ciochină, R.S. Sustainable Entrepreneurship in SMEs: A Business Performance Perspective. Sustainability 2016, 8, 342. [CrossRef] 
72. Kearney, A.T. Don't Give up on Millennials. Available online: https:/ /www.atkearney.com/america250/ don-t-give-up-on-millennials (accessed on 30 January 2017).

73. Hair, J.F.; Ringle, C.M.; Sarstedt, M. From the Special Issue Guest Editors. J. Mark. Theory Pract. 2011, 19, 135-138.

74. Henseler, J.; Dijkstra, T.K.; Sarstedt, M.; Ringle, C.M.; Diamantopoulos, A.; Straub, D.W. Common beliefs and reality about PLS comments on Rönkkö and Evermann. Organ. Res. Method 2014, 17, 182-209. [CrossRef]

75. Hu, L.; Bentler, P.M. Cutoff criteria for fit indexes in covariance structure analysis: Conventional criteria versus new alternatives. Struct. Equ. Model. Multidiscip. J. 1999, 6, 1-55. [CrossRef]

76. Henseler, J.; Hubona, G.; Ray, P.A. Using PLS path modeling in new technology research: Updated guidelines. Ind. Manag. Data Sys. 2016, 116, 2-20. [CrossRef]

77. Barclay, D.; Higgins, C.; Thompson, R. The partial least squares (PLS) approach to causal modeling: Personal computer adoption and use as an illustration. Technol. Studi. 1995, 2, 285-309.

78. Chin, W.W. The partial least squares approach to structural equation modeling. In Modern Methods for Business Research; Marcoulides, G.A., Ed.; Lawrence Erlbaum: Mahwah, NJ, USA, 1998; pp. 295-358.

79. Henseler, J.; Ringle, C.M.; Sinkovics, R.R. The use of partial least squares path modeling in international marketing. Adv. Int. Mark. 2009, 20, 277-320.

80. Yi, M.Y.; Davis, F.D. Developing and validating an observational learning model of computer software training and skill acquisition. Inf. Sys. Res. 2003, 14, 146-169. [CrossRef]

81. Fornell, C.; Larcker, D.F. Evaluating structural equation models with unobservable variables and measurement error. J. Mark. Res. 1981, 18, 39-50. [CrossRef]

82. Diamantopoulos, A.; Siguaw, J.A. Formative versus reflective indicators in organizational measure development: A comparison and empirical illustration. Br. J.Manag. 2006, 17, 263-282. [CrossRef]

83. Hair, J.F.; Hult, G.T.M.; Ringle, C.M.; Sarstedt, M. A Primer on Partial Least Squares Structural Equation Modeling (PLS-SEM); Sage Publication: Los Angeles, CA, USA, 2014.

84. Cohen, J. Statistical Power Analysis for the Behavioral Sciences; Lawrence Erlbaum: Mahwah, NJ, USA, 1988.

(C) 2017 by the authors. Licensee MDPI, Basel, Switzerland. This article is an open access article distributed under the terms and conditions of the Creative Commons Attribution (CC BY) license (http:/ / creativecommons.org/licenses/by/4.0/). 